\title{
\#USGS
}

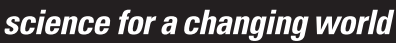

Prepared in cooperation with the Wisconsin Department of Transportation

\section{Simulation of the Shallow Groundwater-Flow System near the Hayward Airport, Sawyer County, Wisconsin}

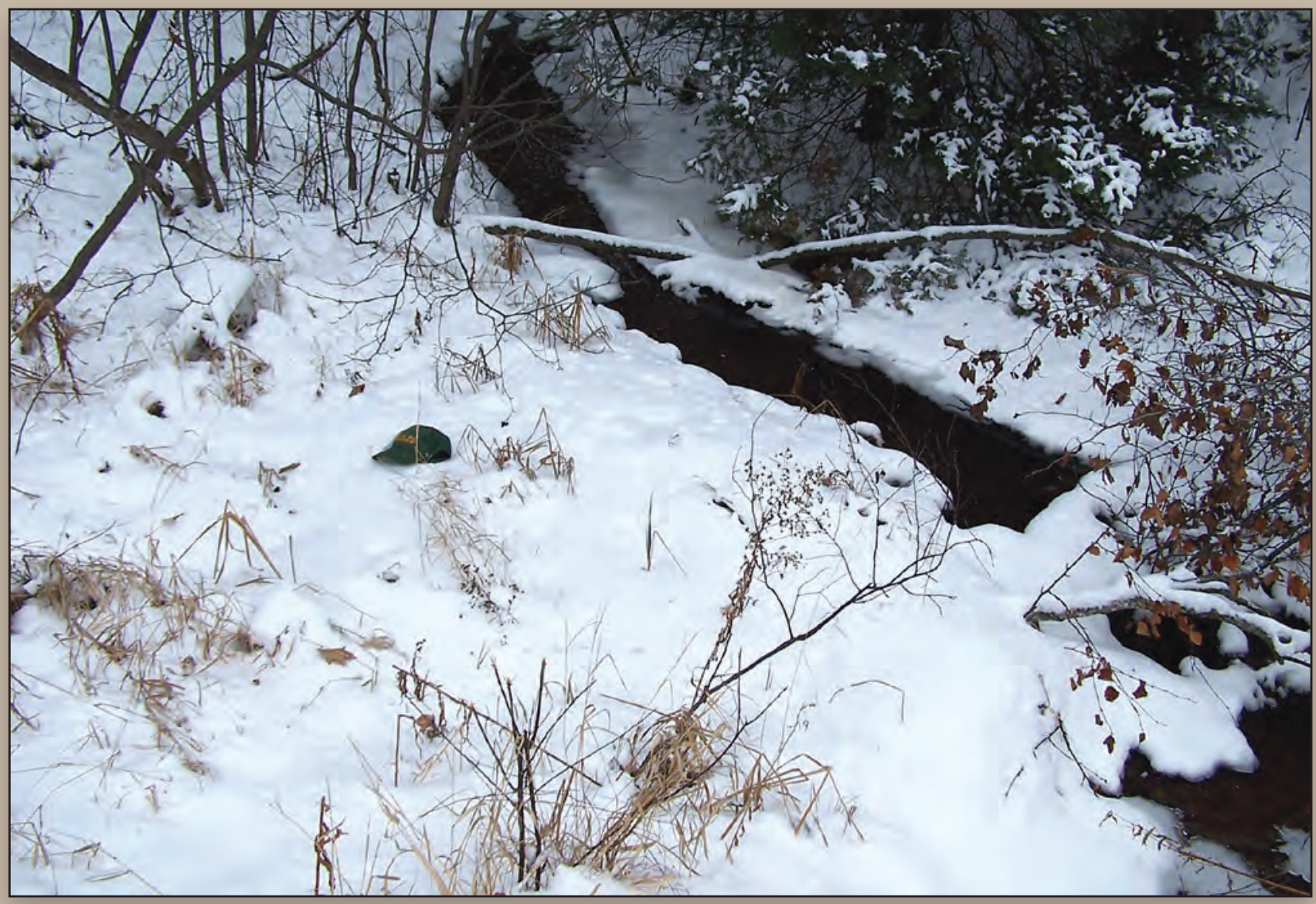

Scientific Investigations Report 2010-5049 
Cover: Photograph showing northern tributary stream to the Namekagon River, Wisconsin. 


\section{Simulation of the Shallow Groundwater-Flow System near the Hayward Airport, Sawyer County, Wisconsin}

By Randall J. Hunt, Paul F. Juckem, and Charles P. Dunning

Prepared in cooperation with the Wisconsin Department of Transportation

Scientific Investigations Report 2010-5049 


\title{
U.S. Department of the Interior \\ KEN SALAZAR, Secretary
}

\section{U.S. Geological Survey \\ Marcia K. McNutt, Director}

\section{U.S. Geological Survey, Reston, Virginia: 2010}

\begin{abstract}
For more information on the USGS — the Federal source for science about the Earth, its natural and living resources, natural hazards, and the environment, visit http://www.usgs.gov or call 1-888-ASK-USGS

For an overview of USGS information products, including maps, imagery, and publications, visit http://www.usgs.gov/pubprod

To order this and other USGS information products, visit http://store.usgs.gov
\end{abstract}

Any use of trade, product, or firm names is for descriptive purposes only and does not imply endorsement by the U.S. Government.

Although this report is in the public domain, permission must be secured from the individual copyright owners to reproduce any copyrighted materials contained within this report.

Suggested citation:

Hunt, R.J., Juckem, P.F., and Dunning, C.P., 2010, Simulation of the shallow groundwater-flow system near the Hayward Airport, Sawyer County, Wisconsin: U.S. Geological Survey Scientific Investigations Report 2010-5049, 14 p. 


\section{Contents}

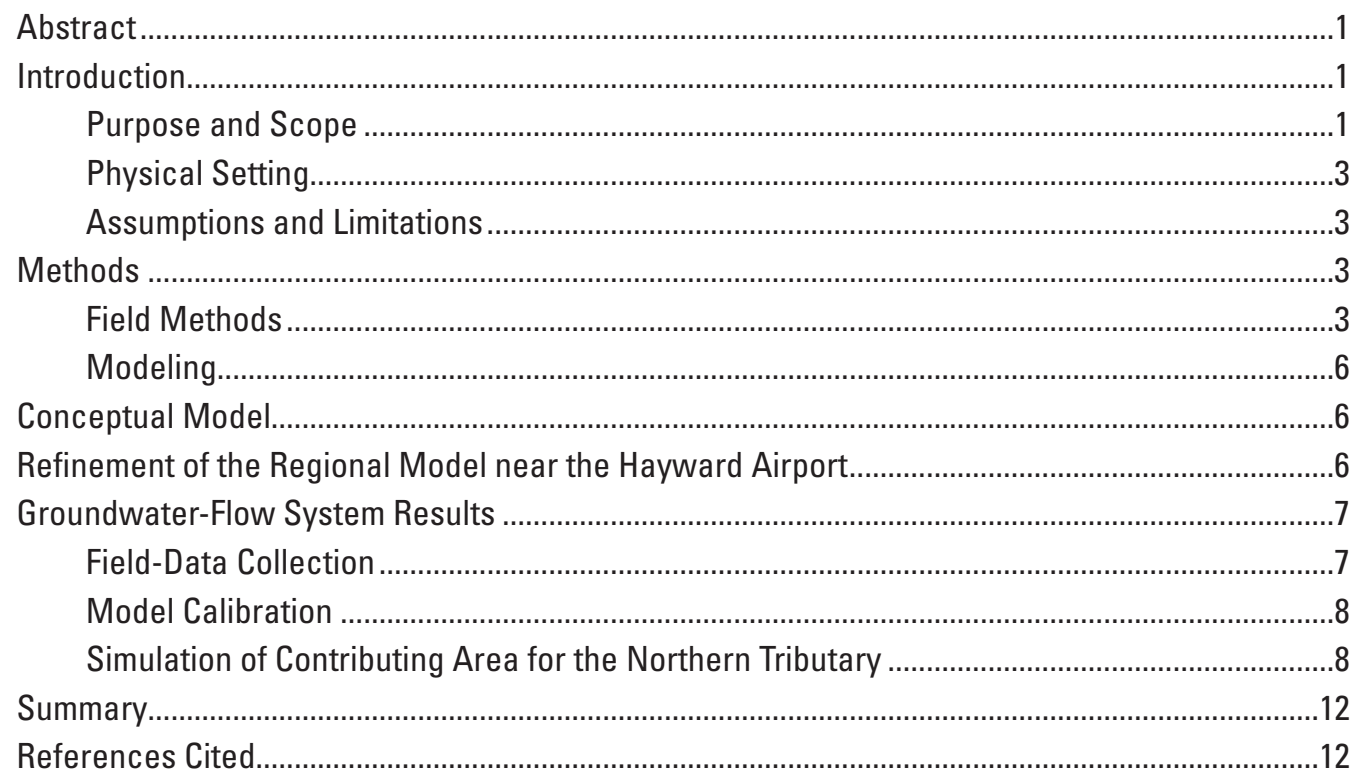

\section{Figures}

Figure 1. Map showing location of the Hayward Airport, Northern Tributary, surface water level measurements, and aquifer zones and linesinks used to simulate groundwater in the refined groundwater-flow model in

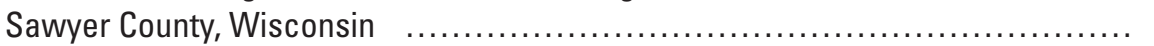

Figure 2A. Map showing results of surface-water measurements in the Northern

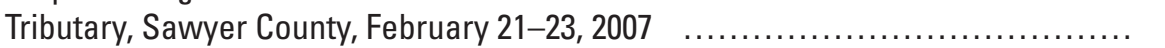

Figure 2B. Map showing results of groundwater levels and flow measurements in the Northern Tributary, Sawyer County, February $21-23,2007 \ldots \ldots \ldots \ldots \ldots \ldots \ldots \ldots \ldots$

Figure 3. Graphs showing observed and simulated flows and groundwater levels for the

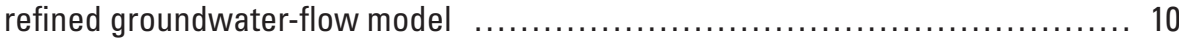

Figure 4. Map showing simulated contributing area delineated using particle tracking in the refined groundwater-flow model 


\section{Tables}

Table 1. Surface-water and groundwater levels measured February 21-23, 2007, during the real-time kinematic (RTK) global positioning system (GPS)

survey near the Hayward Airport, Sawyer County, Wisconsin

Table 2. Observed and simulated values, residuals (observed minus simulated values), and parameter-estimation weight

Table 3. Parameter values and composite scaled sensitivity resulting from parameter estimation

\section{Conversion Factors, Datums, and Abbreviations}

Conversion Factors

\begin{tabular}{|c|c|c|}
\hline Multiply & By & To obtain \\
\hline \multicolumn{3}{|c|}{ Length } \\
\hline inch (in.) & 2.54 & centimeter $(\mathrm{cm})$ \\
\hline foot (ft) & 0.3048 & meter $(\mathrm{m})$ \\
\hline \multicolumn{3}{|c|}{ Flow rate } \\
\hline cubic foot per second $\left(\mathrm{ft}^{3} / \mathrm{s}\right)$ & 0.02832 & cubic meter per second $\left(\mathrm{m}^{3} / \mathrm{s}\right)$ \\
\hline cubic foot per day $\left(\mathrm{ft}^{3} / \mathrm{d}\right)$ & 0.02832 & cubic meter per day $\left(\mathrm{m}^{3} / \mathrm{d}\right)$ \\
\hline inch per year (in/yr) & 25.4 & millimeter per year (mm/yr) \\
\hline \multicolumn{3}{|c|}{ Hydraulic conductivity* } \\
\hline foot per day (ft/d) & 0.3048 & meter per day $(\mathrm{m} / \mathrm{d})$ \\
\hline
\end{tabular}

Datums

Vertical coordinate information is referenced to the North American Vertical Datum of 1988 (NAVD 88).

Horizontal coordinate information is referenced to the North American Datum of 1983 as adjusted for Wisconsin in 1997 (NAD 83 (97)).

*Hydraulic conductivity: The standard unit for hydraulic conductivity is cubic foot per day per square foot of aquifer cross-sectional area $\left(\mathrm{ft}^{3} / \mathrm{d} / \mathrm{ft}^{2}\right)$. In this report, the mathematically reduced form, foot per day $(\mathrm{ft} / \mathrm{d})$, is used for convenience.

Abbreviations

GPS global positioning system

PEST parameter-estimation code (Doherty, 2010)

RTK real-time kinematic

USGS U.S. Geological Survey

UTM Universal Transverse Mercator 


\title{
Simulation of the Shallow Groundwater-Flow System near the Hayward Airport, Sawyer County, Wisconsin
}

\author{
By Randall J. Hunt, Paul F. Juckem, and Charles P. Dunning
}

\section{Abstract}

There are concerns that removal and trimming of vegetation during expansion of the Hayward Airport in Sawyer County, Wisconsin, could appreciably change the character of a nearby cold-water stream and its adjacent environs. In cooperation with the Wisconsin Department of Transportation, a two-dimensional, steady-state groundwater-flow model of the shallow groundwater-flow system near the Hayward Airport was refined from a regional model of the area. The parameter-estimation code PEST was used to obtain a best fit of the model to additional field data collected in February 2007 as part of this study. The additional data were collected during an extended period of low runoff and consisted of water levels and streamflows near the Hayward Airport. Refinements to the regional model included one additional hydraulic-conductivity zone for the airport area, and three additional parameters for streambed resistance in a northern tributary to the Namekagon River and in the main stem of the Namekagon River. In the refined Hayward Airport area model, the calibrated hydraulic conductivity was 11.2 feet per day, which is within the 58.2 to 7.9 feet per day range reported for the regional glacial and sandstone aquifer, and is consistent with a silty soil texture for the area. The calibrated refined model had a best fit of 8.6 days for the streambed resistance of the Namekagon River and between 0.6 and 1.6 days for the northern tributary stream. The previously reported regional groundwater-recharge rate of 10.1 inches per year was adjusted during calibration of the refined model in order to match streamflows measured during the period of extended low runoff; this resulted in an optimal groundwaterrecharge rate of 7.1 inches per year during this period. The refined model was then used to simulate the capture zone of the northern tributary to the Namekagon River.

\section{Introduction}

There are concerns that removal and trimming of vegetation as part of an expansion of the Hayward Airport in Sawyer County, Wisconsin (fig. 1) could appreciably change the character of a small stream and its adjacent environs. This stream is a tributary to the Namekagon River and is referred to herein as "Northern Tributary" (an unofficial name that is only used for the purposes of this report). During site visits by the U.S. Geological Survey (USGS) in January and February 2007, the Northern Tributary appeared to be ephemeral in its upper reaches and perennial in its lower reaches owing to the distribution of groundwater discharge. Knowledge of the sources of streamflow is needed to better estimate potential effects caused by nearby vegetation change. Delineation of the area that contributes groundwater flow to the Northern Tributary was a primary concern because it is considered a cold-water/trout habitat. This report describes a screening-level study done by the USGS, in cooperation with the Wisconsin Department of Transportation, to estimate the areas that contribute groundwater to the Northern Tributary so that state and federal regulators could assess the potential for adverse impacts to the cold-water resource. Study objectives included collection of field data near the airport area so that a regional model of the area could be refined and used to simulate the contributing area to the Northern Tributary.

\section{Purpose and Scope}

This report describes the refinement and recalibration of a two-dimensional, steady-state groundwater-flow model, which is described in detail in Juckem and Hunt (2007). 


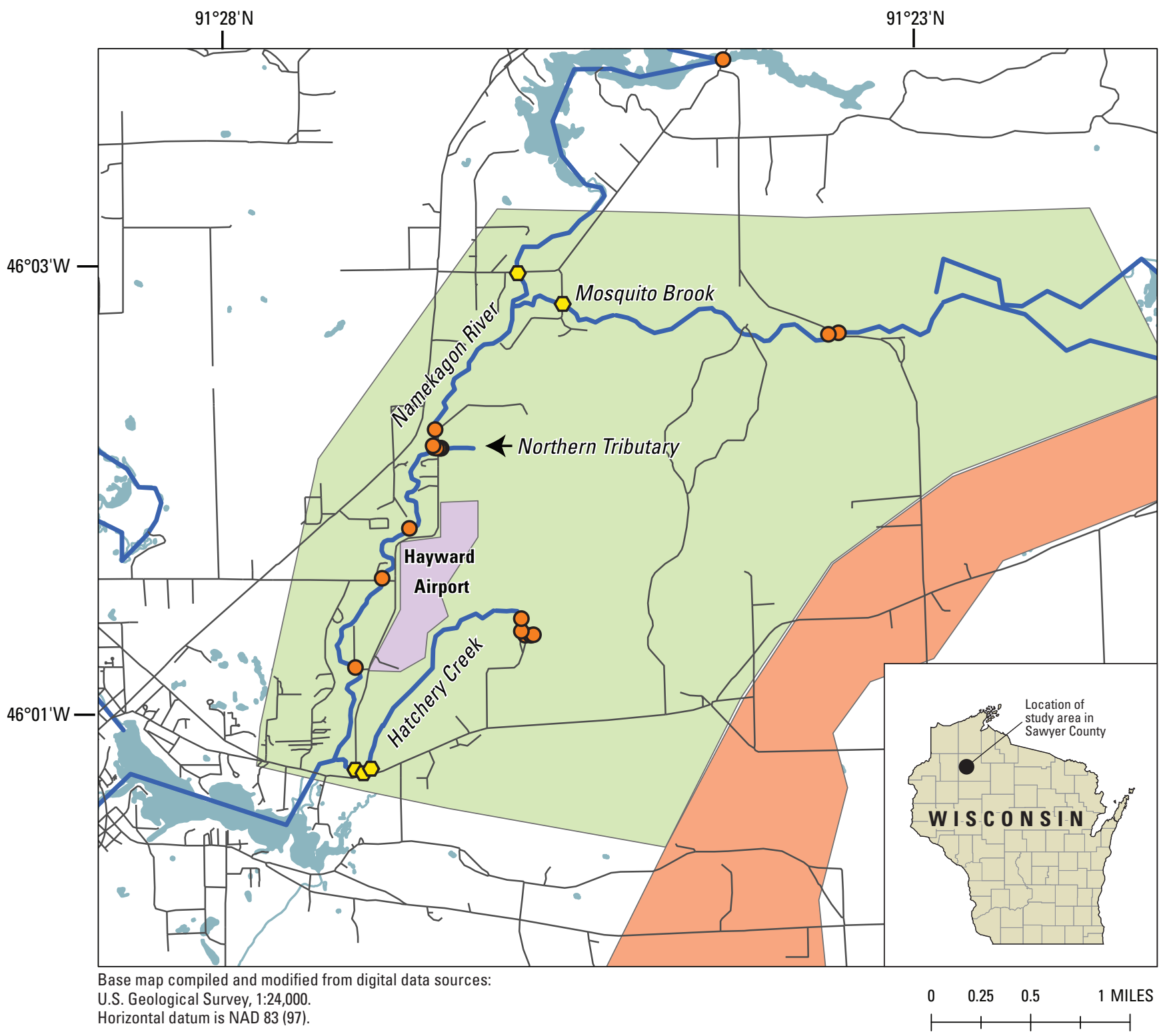

EXPLANATION

\begin{tabular}{l} 
General extent of the Hayward Airport \\
Local hydraulic-conductivity zone \\
Glacial thrust-mass zone of Juckem and Hunt (2007) \\
GFLOW linesinks \\
Rivers and lakes \\
\hline Roads \\
$\quad$ Water level estimated from ice surface \\
O Surface-water levels
\end{tabular}

Figure 1. Location of the Hayward Airport, Northern Tributary, surface water level measurements, and aquifer zones and linesinks used to simulate groundwater in the refined groundwater-flow model in Sawyer County, Wisconsin. 
Additional groundwater-level and streamflow data collected near the Hayward Airport formed the basis for refinement and recalibration of the regional model. The refined, recalibrated model of the shallow hydrologic system near the Hayward Airport was used as a tool to delineate the groundwater-contributing area of the Northern Tributary. The refinement and recalibration of the model is discussed, and the results of the contributing-area simulation are described.

\section{Physical Setting}

The regional setting is described by Juckem and Hunt (2007). Important features of the local setting near the Hayward Airport are briefly described here. The airport is in northwestern Sawyer County along the southern shores of the Namekagon River. The sand and gravel aquifer has relatively high horizontal hydraulic conductivity (Juckem and Hunt, 2007) and no laterally extensive confining beds. On the northern boundary of the airport is the Northern Tributary, a first-order stream (no tributaries) reported to have cold-water-habitat characteristics (Sather and Threinen, 1969; Pratt, 1982). The local groundwater-flow system is characterized by terrestrial recharge, with discharge primarily to the Namekagon River and secondarily to other rivers and streams.

\section{Assumptions and Limitations}

The groundwater and surface-water systems were assumed to be in close hydraulic connection in the modeled area given the coarse nature of the unconsolidated sediments, high net-annual precipitation, presence of springs and perennial headwater streams, and previous modeling. It follows then that elevations of surface-water features can be assumed to be representative of the groundwater system. Areal two-dimensional assumptions were appropriate for the model because the groundwater-flow system is thin and areally extensive; however, because areal two-dimensional assumptions may not be representative within two to three aquifer thicknesses of a surface-water feature (Haitjema, 1995, 2006; Hunt and others, 2003), simulated groundwater levels near surface-water features can be considered approximate only. Moreover, the streambed-resistance parameter values used to match measured streamflows also can be considered only approximate because simulated streamflow depends on simulated heads near the stream in addition to streambed resistance. Therefore, calibrated values of streambed resistance will include artifacts that result from the effects of the areal two-dimensional assumption on heads near surface-water features. Steady-state simulations were assumed appropriate for this study and can be expected to result in an estimate of the high range of system response to a hydrologic stress, because steady-state simulations ignore groundwater release from storage. Although the model was refined by adding some additional parameterization in the Hayward Airport area, small-scale properties of the groundwater system (for example, local variations in hydraulic conductivity and recharge) were not investigated during this study and are approximated in the refined model. Finally, the field measurements were made during a time of below-normal precipitation, as evidenced by the low streamflow measurement of record occurred during this year at a long-term streamgage in the study area (USGS 05331833 Namekagon River at Leonards, Wisconsin). Model parameters calibrated to these measurements reflect these drier conditions and may not correspond to more normal precipitation conditions.

\section{Methods}

This study included refining the regional groundwater-flow model of Juckem and Hunt (2007). Additional field data were collected in the Hayward Airport area for use in calibration of the refined local model.

\section{Field Methods}

Field data were collected in the Hayward Airport area (fig. 1) as part of this study. A real-time kinematic (RTK) global positioning system (GPS) was used to survey horizontal and vertical locations of interest around the Northern Tributary near the Hayward Airport during February 21-23, 2007. This RTK-GPS system is capable of providing sub-inch level accuracy by differentially correcting GPS signals recorded at two separate GPS receivers (Wolf and Ghilani, 2002). The field survey was referenced to the Universal Transverse Mercator (UTM) coordinate system and the NAD83 (97) horizontal and NAVD88 vertical datums. Streamflow was measured at three locations on the Northern Tributary within $200 \mathrm{ft}$ of the culvert at Airport Road (fig. 2A) during February 21-23, 2007. Streamflow was measured using a 3-in. modified Parshall flume (Rantz and others, 1982). The flume was installed slightly above the streambed, with an attached rubber apron secured to the streambed sediment upstream of the flume. This design allowed water to pool upstream of the flume and maintain free-fall conditions at the exit of the flume. The flume was leveled and water levels in an attached stilling well were recorded until the water level in the stilling well, and thus streamflow, had stabilized. Streamflow was determined from the water level (gage height) based on Rantz and others (1982, table 14).

Piezometers were installed in and around the bed of the Northern Tributary and in the area of the headwater wetland to investigate local groundwater/surface-water interaction. For each piezometer, a 0.5 -ft long screen was set approximately 1 to $2 \mathrm{ft}$ below land surface. The depth to water (or height above the stream stage) was measured until the water level stabilized in each piezometer. A reference point at each piezometer was established during the RTK-GPS survey to associate the measured water level in each piezometer with an elevation. 


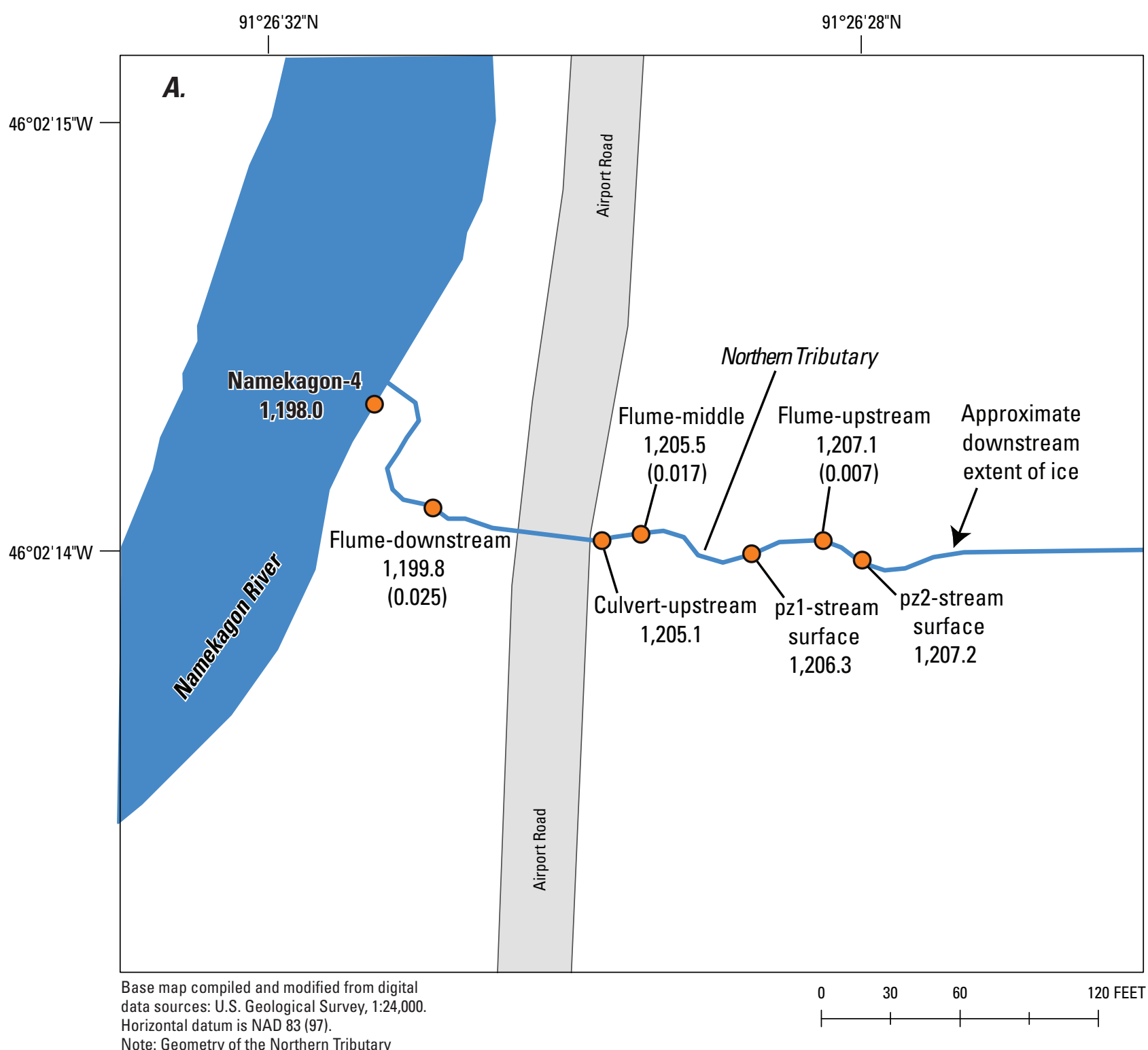

.

Note: Geometry of the Northern Tributary

channel is approximate.

\section{EXPLANATION}

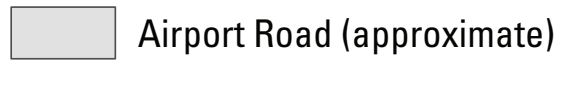

Rivers and streams

Flume-upstream

1,207.1 $\bigcirc$ Location and name of streamflow measurement-Number is surface-water $(0.007)$ elevation in feet above NAVD 88 (see table 1). Number in parentheses is flow where measured, in cubic feet per second

Figure 2A. Results of surface-water measurements in the Northern Tributary, Sawyer County, February 21-23, 2007. 


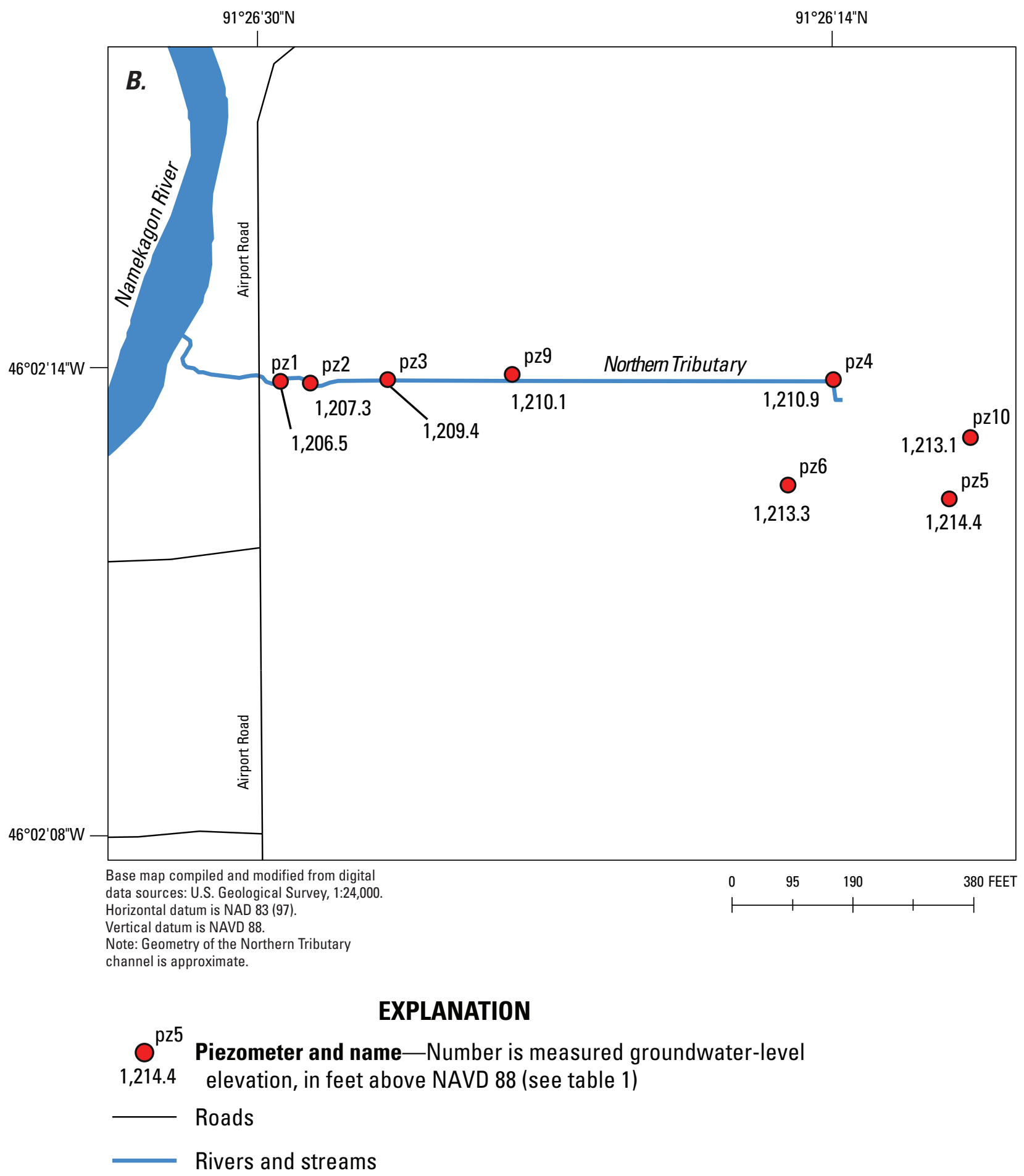

Figure 2B. Results of groundwater levels and flow measurements in the Northern Tributary, Sawyer County, February 21-23, 2007. 


\section{Modeling}

An analytic-element groundwater-flow model, using the computer program GFLOW (Haitjema, 1995), was used to simulate the groundwater system and its interaction with surface-water features. Hunt (2006) gives a review of applications of the analytic element method and Haitjema (1995) discusses the underlying concepts and mathematics of the method in detail. A brief description of analytic element methods is as follows.

An infinite aquifer is assumed in analytic-element modeling. To construct an analytic-element model, features important for controlling groundwater flow (for example, wells and surface-water features) are entered as mathematical elements or strings of elements. The amount of detail specified for the features depends on distance from the area of interest. Each element is represented by an analytic solution. The effects of these individual solutions are added together to form a solution for any location in the simulated groundwater-flow system. In the model code used here, the analytic elements are two dimensional and are used only to simulate steadystate conditions (water levels that do not vary with time). The analytic-element method and comparisons of analytic-element to finite-difference numerical-model techniques have been discussed by others (Haitjema, 1995; Hunt and Krohelski, 1996; Hunt and others 1998, 2003).

The GFLOW model was calibrated by means of parameter-estimation techniques. The advantages of parameter-estimation models are discussed by Poeter and Hill (1997) and Hill (1998). Briefly, the primary benefit of a properly prepared parameter-estimation model over typical trial-and-error calibration is the ability to calculate parameter values (for example, hydraulic conductivity and streambed resistance) that are a quantified best fit between simulated model output and observed data (groundwater levels and streamflows). In addition, parameter correlation and parameter sensitivity can be quantified and assessed. In this study, the GFLOW model was coupled with the parameter-estimation code PEST (Doherty, 2010).

\section{Conceptual Model}

A conceptual model is a simplification of the hydrologic system that is necessary because inclusion of all hydrogeologic complexities into a model is not feasible. Steps in the development of the conceptual model include: (1) characterization of the aquifer(s), (2) identification of sources and sinks of water, and (3) identification and delineation of hydrologic boundaries in the area of interest. The conceptual model of the hydrologic system is described in this section.
Although the regional groundwater system comprises shallow and deep aquifers (Juckem and Hunt, 2007), groundwater flow is dominated by flow through the shallow aquifer, which consists of glacial deposits that are composed primarily of sandy till and stream deposits that are about $100-\mathrm{ft}$ thick near the Hayward Airport. The deep aquifer consists of Cambrian sandstones (roughly 100-ft thick near Grindstone Lake) that pinch out east of the Hayward Airport. Where the sandstone is absent, glacial sediments are deposited directly onto crystalline bedrock. The sandstone and glacial deposits were simulated as a single aquifer in the groundwater-flow model because the ability of the sandstone to transmit water is less than that of the overlying glacial aquifer, meaning that the groundwater-flow system is dominated by the glacial deposits. Moreover, Juckem and others (2003) demonstrated that simulated base-flow reductions in nearby Grindstone Creek owing to pumping agreed to within 1 percent when results from a one-layer model were compared to results from a four-layer model that explicitly included the sandstone and glacial aquifers.

The distant boundaries for the system are directly derived from the regional model of Juckem and Hunt (2007); however, the local boundaries are important for the modeling objective because the problem is one of distribution of flow between two competing discharge points or "sinks" to the groundwater system. The first possible sink is the regionally important Namekagon River. The second possible sink for the local groundwater-flow system is the small tributary of interest, the Northern Tributary. Thus, the conceptual model includes local infiltration of precipitation that recharges the groundwater system, which is in turn discharged to either the Northern Tributary or the Namekagon River.

\section{Refinement of the Regional Model near the Hayward Airport}

The regional groundwater-flow model of Juckem and Hunt (2007) was refined to improve simulation of local scale groundwater flow near the Hayward Airport. For the refined model simulations, properties of the regional model remained unchanged except near the Hayward Airport. Modifications to geologic properties in the model included the addition of one zone in which the hydraulic conductivity was allowed to vary from the regional value (fig. 1). The Namekagon River shoreline location also was refined for local simulations near the Hayward Airport by adding detail based on USGS topographic maps. Small tributaries not included in the regional model, such as the Northern Tributary, were added using the site hydrography. Streambed resistance of the Namekagon River was changed from 0.5 to 5 days owing to results of initial sensitivity runs that showed the regional model value was not representative of heads and flows in the Hayward Airport area. Streambed resistance is defined as the 
streambed-sediment thickness divided by the vertical hydraulic conductivity. For example, the model value of 5 days corresponds to a $1-\mathrm{ft}$ sediment thickness and a vertical hydraulic conductivity of $0.2 \mathrm{ft} / \mathrm{d}$. Initial resistance of the Northern Tributary was specified as 5 days in the location where the stream appeared to be ephemeral and 3 days where perennial. The stages of the Namekagon River, adjacent streams, and the Northern Tributary were specified using the field data collected in February 2007 so that all stage data were contemporaneous and therefore representative of the conditions present when groundwater levels were measured.

\section{Groundwater-Flow System Results}

This section describes field data used for calibration, the calibration of the model, and use of particle tracking to simulate the contributing area to the Northern Tributary.

\section{Field-Data Collection}

Although conducted in winter, results of a 3-day field survey were used to characterize hydrologic conditions near the Northern Tributary (fig. 2 and summarized in table 1). Measured streamflows and water levels of the Northern Tributary are shown in figure $2 A$. Measured water levels in piezometers are shown in figure $2 B$. Streamflow in the Northern Tributary was evident approximately $200 \mathrm{ft}$ upstream of Airport Road (fig. 2A). Farther upstream of this location, the streambed was covered by as much as $3 \mathrm{ft}$ of ice. Augured holes through the ice along the stream channel showed no signs of flowing water along the streambed. Ponded water in the wetland also was frozen completely. Water levels in piezometers PZ1 and PZ2 (fig. 2B and table 1) showed upward gradients relative to the stream stage (fig. $2 A$ and table 1$)$, as expected, given the measurements of increasing base flow in the downstream direction. Water levels in piezometers PZ3 and PZ4 (fig. $2 B$ ) were below the streambed, indicating that
Table 1. Surface-water and groundwater levels measured February 21-23, 2007, during the real-time kinematic (RTK) global positioning system (GPS) survey near the Hayward Airport, Sawyer County, Wisconsin.

[Wl, water-level elevation was measured directly with the RTK-GPS; ice, the measured elevation is that of frozen water and was inferred to correspond with the stream stage at that location; easting and northing coordinates are referenced to the Universal Transverse Mercator coordinate system, North American Datum of 1983 as adjusted for Wisconsin in 1997; elevation is relative to North American Vertical Datum of 1988]

\begin{tabular}{|c|c|c|c|c|}
\hline Location name & $\begin{array}{c}\text { Easting } \\
\text { (meters) }\end{array}$ & $\begin{array}{l}\text { Northing } \\
\text { (meters) }\end{array}$ & $\begin{array}{c}\text { Water-level } \\
\text { elevation } \\
\text { (feet) }\end{array}$ & Description \\
\hline \multicolumn{5}{|c|}{ Surface-water measurement locations } \\
\hline Flume-upstream & $620,622.25$ & $5,099,353.94$ & $1,207.10$ & Wl \\
\hline Flume-middle & $620,593.88$ & $5,099,354.92$ & $1,205.50$ & Wl \\
\hline Flume-downstream & $620,562.15$ & $5,099,358.75$ & $1,199.82$ & Wl \\
\hline PZ1-stream surface & $620,611.35$ & $5,099,352.21$ & $1,206.30$ & Wl \\
\hline PZ2-stream surface & $620,627.60$ & $5,099,351.30$ & $1,207.21$ & W1 \\
\hline Culvert-upstream & $620,588.39$ & $5,099,353.81$ & $1,205.07$ & Wl \\
\hline Namekagon-1 & $623,210.71$ & $5,102,913.60$ & $1,221.46$ & Wl \\
\hline Namekagon-2 & $621,330.60$ & $5,100,955.89$ & $1,210.82$ & Ice \\
\hline Namekagon-3 & $620,573.17$ & $5,099,524.57$ & $1,198.34$ & Wl \\
\hline Namekagon-4 & $620,553.08$ & $5,099,374.68$ & $1,198.02$ & Wl \\
\hline Namekagon-5 & $620,336.84$ & $5,098,619.27$ & $1,193.75$ & Wl \\
\hline Namekagon-6 & $620,088.40$ & $5,098,158.69$ & $1,191.24$ & W1 \\
\hline Namekagon-7 & $619,841.03$ & $5,097,341.48$ & $1,187.80$ & W1 \\
\hline Hatchery1 & $619,839.95$ & $5,096,403.02$ & $1,189.77$ & Ice \\
\hline Hatchery2 & $621,398.96$ & $5,097,637.36$ & $1,219.34$ & Wl \\
\hline Hatchery3 & $621,449.58$ & $5,097,637.49$ & $1,221.11$ & Wl \\
\hline Hatchery4 & $621,473.50$ & $5,097,641.61$ & $1,222.77$ & Wl \\
\hline Hatchery5 & $621,361.17$ & $5,097,673.99$ & $1,217.47$ & Wl \\
\hline Hatchery6 & $621,363.04$ & $5,097,788.94$ & $1,214.88$ & Wl \\
\hline Hatchery7 & $619,914.89$ & $5,096,371.24$ & $1,191.24$ & Ice \\
\hline Hatchery8 & $619,984.19$ & $5,096,412.39$ & $1,193.95$ & Ice \\
\hline Mosquito_Brook-1 & $624,271.33$ & $5,100,413.48$ & $1,278.72$ & Wl \\
\hline Mosquito_Brook-2 & $624,176.13$ & $5,100,396.20$ & $1,274.74$ & Wl \\
\hline Mosquito_Brook-3 & $621,739.90$ & $5,100,675.97$ & $1,216.73$ & Ice \\
\hline Location name & $\begin{array}{l}\text { Easting } \\
\text { (meters) }\end{array}$ & $\begin{array}{l}\text { Northing } \\
\text { (meters) }\end{array}$ & $\begin{array}{c}\text { Water-level } \\
\text { elevation } \\
\text { (feet) }\end{array}$ & $\begin{array}{c}\text { Piezometer } \\
\text { bottom } \\
\text { elevation } \\
\text { (feet) }\end{array}$ \\
\hline \multicolumn{5}{|c|}{ Groundwater measurement locations } \\
\hline PZ1 & $620,611.35$ & $5,099,352.21$ & $1,206.54$ & $1,203.76$ \\
\hline PZ2 & $620,627.60$ & $5,099,351.30$ & $1,207.34$ & $1,204.77$ \\
\hline PZ3 & $620,671.99$ & $5,099,352.69$ & $1,209.42$ & $1,208.51$ \\
\hline $\mathrm{PZ4}$ & $620,926.05$ & $5,099,352.68$ & $1,210.88$ & $1,209.51$ \\
\hline PZ5 & $620,991.72$ & $5,099,284.65$ & $1,214.42$ & $1,213.30$ \\
\hline PZ6 & $620,899.74$ & $5,099,293.15$ & $1,213.25$ & $1,213.05$ \\
\hline PZ9 & $620,743.05$ & $5,099,356.43$ & $1,210.13$ & $1,209.50$ \\
\hline PZ10 & $621,004.05$ & $5,099,320.49$ & $1,213.07$ & $1,211.42$ \\
\hline
\end{tabular}

groundwater was not discharging into the tributary stream during February 21-23, 2007. Water levels in the wetland piezometers (PZ5, PZ6, and PZ10) were 1.5 to $2.5 \mathrm{ft}$ below land surface. Piezometer PZ9 was installed adjacent to the Northern Tributary (ig. $2 B$ ). 


\section{Model Calibration}

Groundwater levels from eight piezometers (fig. $2 B$ ) measured during the February 2007 survey were used to calibrate the refined model of the Hayward Airport area. These measured values were contemporaneous and had a datum consistent with measurements of stage on the Namekagon River, adjoining tributaries, and the Northern Tributary. Streamflows measured during February 2007 also were used to calibrate the refined model. Flows measured in February 2007 were considered to be entirely base flow (the component of streamflow derived solely from groundwater discharge), because winter in Wisconsin is a period of low or negligible stormflow. Thus, the measured streamflows were used directly as target values at the three flume stations. In addition, an observed base-flow value of 0.0 was entered for the area where the stream transitioned from ephemeral to perennial (extent of ice in fig. $2 A$ ), and one low-weight target was entered to evaluate how the conditions simulated in the February 2007 calibrated run compared to the previous base-flow value for Hatchery Creek reported by Juckem and Hunt (2007).

The regional hydraulic-conductivity values were not varied from the values of Juckem and Hunt (2007). The regional recharge value, the local hydraulic-conductivity zone near the Hayward Airport, and the local streambed resistance of the Namekagon River and the Northern Tributary were estimated during calibration. The calibration was performed by coupling the groundwater-flow model GFLOW to the parameter-estimation program PEST (Doherty, 2010). The parameter estimation varied the GFLOW-parameter values to achieve a best fit between simulated and observed base flows and groundwater levels. Weights were assigned to the observed values that reflect their relative importance to the overall modeling objective, and thus directly affect the fit between simulated and measured values. In PEST, the higher weights represent higher importance in the parameter estimation. In this study, the most downstream flume target was the most important target (highest weight) because the objective of this modeling was to identify the entire groundwater-contributing area for the Northern Tributary. Although other targets are included in the calibration, the emphasis of the calibration was not on simulating the local groundwater levels or the distribution of groundwater flow within the Northern Tributary. Rather, the primary objective of the modeling was to simulate the distribution of flow between the entire Northern Tributary (as represented by the most downstream base-flow measurement) and the other potential sink for water recharged in the Hayward Airport area - the adjacent Namekagon River. The weights assigned to each calibration target, along with residuals derived from the calibrated-model solution, are listed in table 2 .

The resulting calibrated-model hydraulic conductivity value (table 3) is within the 58.2 to $7.9 \mathrm{ft} / \mathrm{d}$ range reported for the regional glacial and sandstone aquifer by Juckem and Hunt (2007), and are consistent with silty soil reported by Clayton (1984). Regional recharge and local hydraulic conductivity were the most sensitive parameters (had the largest effect on the calibration) of the calibrated parameters (table 3). The calibrated-recharge value ( $7.1 \mathrm{in} / \mathrm{yr}$ ) was about 70 percent of the value ( $10.1 \mathrm{in} / \mathrm{yr})$ used by Juckem and Hunt (2007) and reflects persistent low-precipitation conditions that characterized the area during this study. Results from the calibrated model agreed well with the observed downstream-flume measurement (table 2, fig. 3). Other head and flow measurements were less well simulated (fig. 3) because they were given lesser weight in the parameter-estimation process, but are still considered acceptable given the stated modeling objective.

\section{Simulation of Contributing Area for the Northern Tributary}

The calibrated model was used to estimate the configuration of the land-surface area that contributes groundwater recharge for the Northern Tributary. The contributing area of the stream is the land area with the same horizontal extent as that part of the aquifer that contributes groundwater flow to the stream. The contributing area of the Northern Tributary was delineated by forward particle tracking using particles placed near the Northern Tributary. Simulated particles of water were placed at the water table and tracked forward in time using the calibrated model. The contributing area simulated by the calibrated model is shown in figure 4; it is about $300 \mathrm{ft}$ wide and about 15,000 ft long. 
Table 2. Observed and simulated values, residuals (observed minus simulated values), and parameter-estimation weight. $\left[\mathrm{ft}^{3} / \mathrm{d}\right.$, cubic foot per day]

\begin{tabular}{lccrcc}
\hline \multicolumn{1}{c}{ Location name } & Observed & Simulated & Residual & Units & Weight \\
\hline pz6 & $1,213.25$ & $1,215.40$ & -2.15 & feet & 1 \\
pz5 & $1,214.42$ & $1,218.58$ & -4.16 & feet & 1 \\
pz10 & $1,213.07$ & $1,218.69$ & -5.62 & feet & 1 \\
pz4 & $1,210.88$ & $1,215.40$ & -4.52 & feet & 1 \\
pz9 & $1,210.13$ & $1,210.06$ & .07 & feet & 1 \\
pz3 & $1,209.42$ & $1,207.88$ & 1.54 & feet & 1 \\
pz2 & $1,207.34$ & $1,206.16$ & 1.18 & feet & 1 \\
pz1 & $1,206.54$ & $1,205.37$ & 1.17 & feet & 1 \\
Flume-upstream & 605 & 2,266 & $-1,661$ & $\mathrm{ft}^{3} / \mathrm{d}$ & $1.0 \mathrm{E}-03$ \\
Flume-middle & 1,469 & 2,096 & -627 & $\mathrm{ft}^{3} / \mathrm{d}$ & $1.0 \mathrm{E}-02$ \\
Flume-downstream & 2,160 & 2,240 & -80 & $\mathrm{ft}^{3} / \mathrm{d}$ & $1.0 \mathrm{E}-01$ \\
Hatchery Creek & 144,288 & 135,408 & 8,880 & $\mathrm{ft}^{3} / \mathrm{d}$ & $1.0 \mathrm{E}-06$ \\
Approximate downstream extent of ice & 0 & 2,429 & $-2,429$ & $\mathrm{ft}^{3} / \mathrm{d}$ & $1.0 \mathrm{E}-04$ \\
Namekagon at Leonards & $6.39 \mathrm{E}+06$ & $6.39 \mathrm{E}+06$ & -997 & $\mathrm{ft}^{3} / \mathrm{d}$ & $1.0 \mathrm{E}-03$ \\
\hline
\end{tabular}

Table 3. Parameter values and composite scaled sensitivity resulting from parameter estimation.

[in/yr, inch per year; ft/d, foot per day]

\begin{tabular}{lccc}
\hline \multicolumn{1}{c}{ Parameter name } & $\begin{array}{c}\text { Initial } \\
\text { value }\end{array}$ & $\begin{array}{c}\text { Calibrated } \\
\text { value }\end{array}$ & $\begin{array}{c}\text { Composite } \\
\text { scaled } \\
\text { sensitivity }\end{array}$ \\
\hline Recharge (in/yr) & 10.1 & 7.1 & 208 \\
Local hydraulic conductivity (ft/d) & 58.2 & 11.2 & 170 \\
Namekagon streambed resistance (days) & 5.0 & 8.6 & 4.4 \\
East Northern Tributary resistance (days) & 5.0 & .6 & 8.7 \\
West Northern Tributary resistance (days) & 3.0 & 1.6 & .5 \\
\hline
\end{tabular}



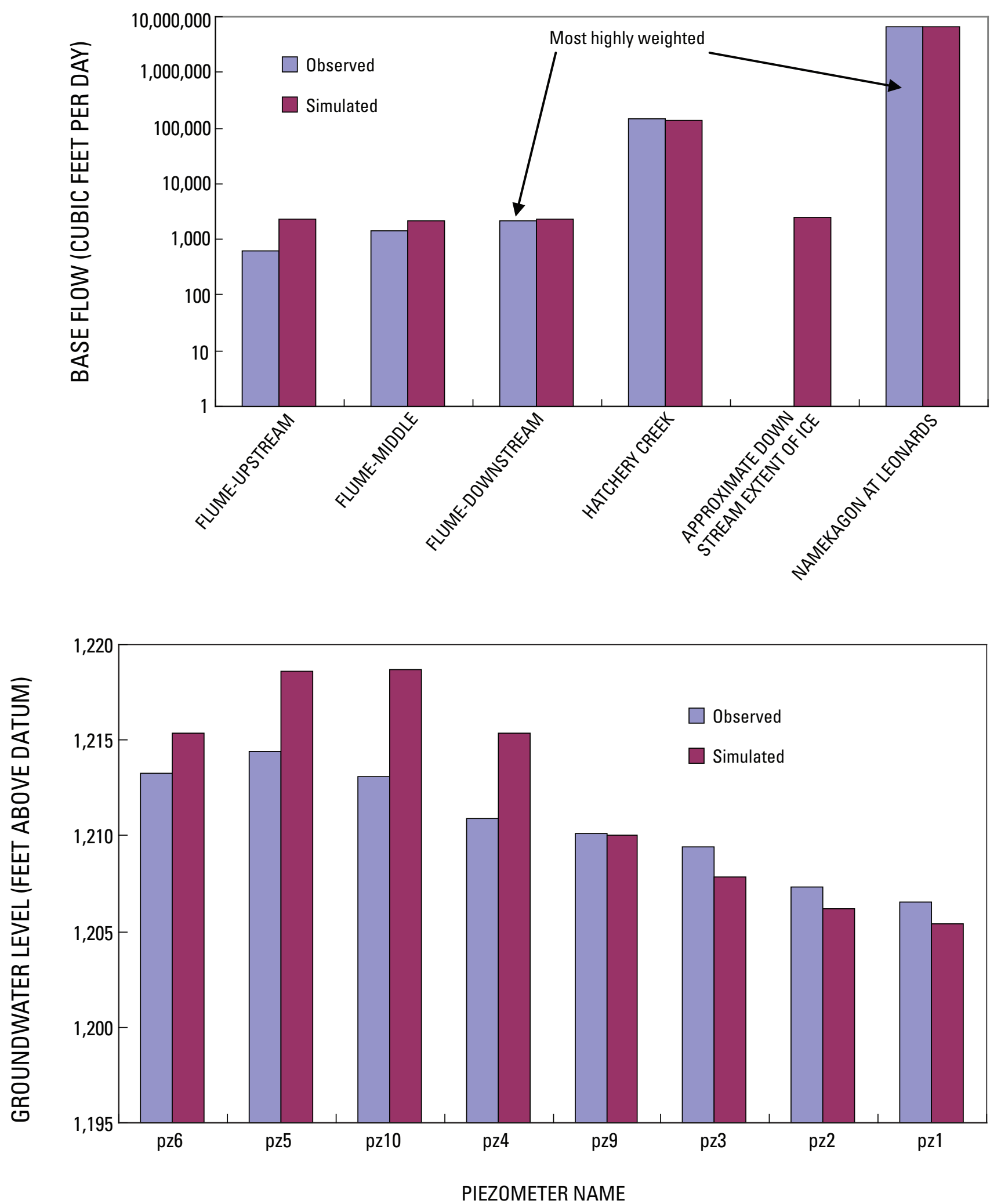

Figure 3. Observed and simulated flows and groundwater levels for the refined groundwater-flow model. Datum is North American Vertical Datum of 1988. 


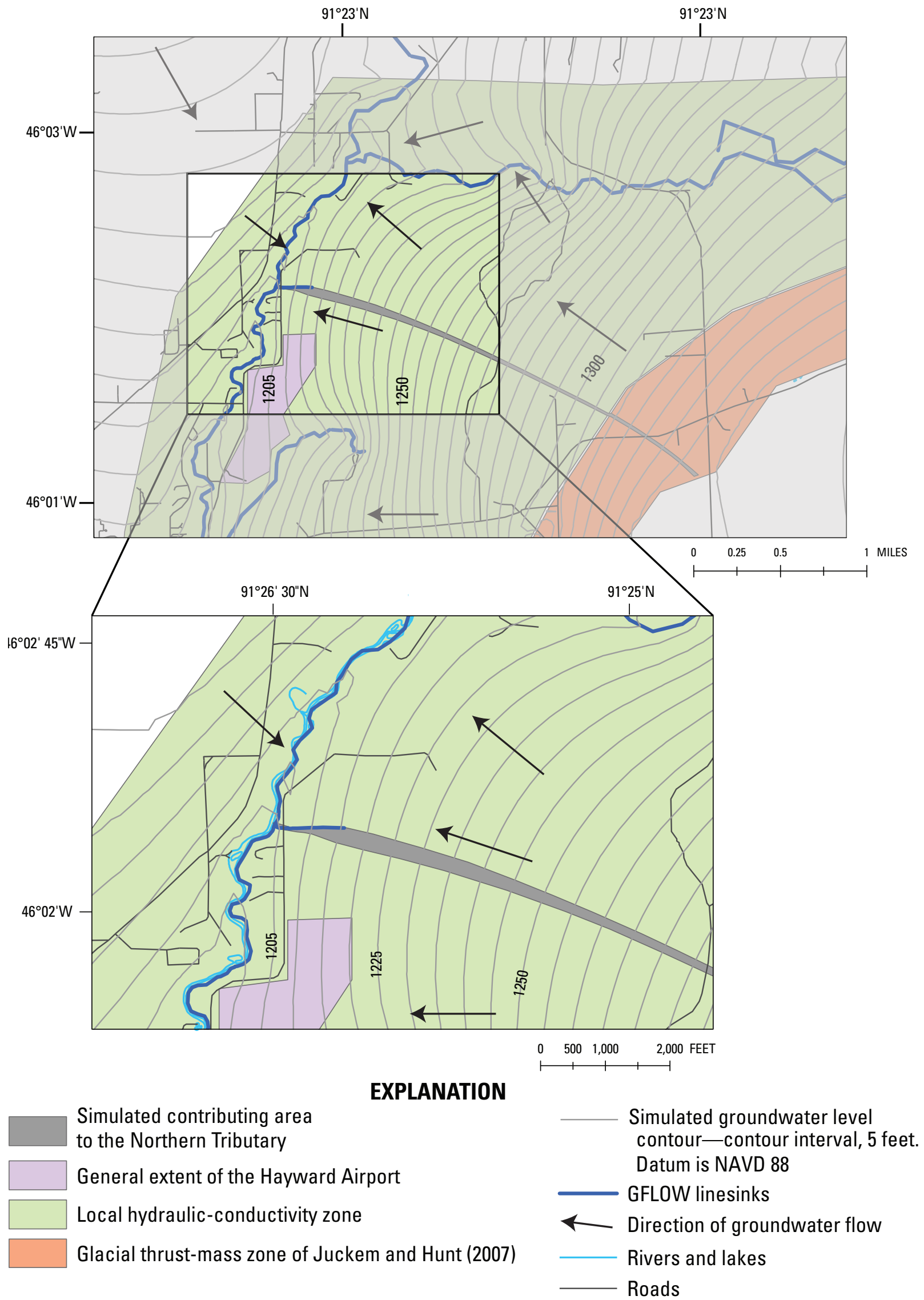

Figure 4. Simulated contributing area delineated using particle tracking in the refined groundwater-flow model. 


\section{Summary}

A hydrologic investigation near the Hayward Airport in Sawyer County, Wisconsin, focused on a small tributary stream ("Northern Tributary") and its adjacent environs. During site visits by the U.S. Geological Survey (USGS) in January and February 2007 (a time of drought in the region), the Northern Tributary was dry in its upper reaches and flowing in its lower reaches owing to the distribution of groundwater discharge. The source of groundwater to the tributary stream was a primary focus of investigation because the stream is considered a cold-water habitat that is maintained by groundwater flow. To estimate the areas that contribute groundwater to the Northern Tributary, a modeling study was done by the USGS, in cooperation with the Wisconsin Department of Transportation. Field data collected from the site were used to refine a regional groundwater-flow model, which was then used to simulate the contributing area to the Northern Tributary.

Water levels along streams in the area of interest were surveyed with a real-time kinematic (RTK) global positioning system (GPS) to refine the geometry and stage of streams in the model. Streamflow was measured with a flume at three locations on the Northern Tributary and ranged from 0.007 to 0.025 cubic feet per second. Piezometers were installed in and around the streambed of the Northern Tributary and in the area of the headwater wetland to investigate local groundwater/surface-water interaction. The streamflows and groundwater levels in piezometers were used to calibrate model-parameter values.

For the refined model, modifications from the regional model included: (1) refinement of local stream geometry and elevation, (2) addition of one zone in which the hydraulic conductivity was allowed to vary from the regional value, (3) additional refinement of streambed resistance for the Namekagon River and along the Northern Tributary, and (4) adjustment of the regional groundwater-recharge rate to account for drought conditions in the region. The calibrated-model values are within the range of parameters reported by Juckem and Hunt (2007) and agreed with an area of silty soil reported by Clayton (1984).

The calibrated model was used to estimate the location of the land surface that contributes groundwater recharge for the Northern Tributary. The contributing area simulated by the calibrated model extends west and southwest of the Northern Tributary and is about 300 feet wide by about 15,000 feet long.

\section{References Cited}

Clayton, L., 1984, Pleistocene geology of the Superior Region, Wisconsin: Wisconsin Geological and Natural History Survey Information Circular 46, 40 p., 1 pl.

Doherty, J., 2010, PEST-Model-independent parameter estimation: Brisbane, Australia, Watermark Numerical Computing. http://www.pesthomepage.org/files/pestman.pdf

Haitjema, H.M., 1995, Analytic element modeling of groundwater flow: San Diego, Calif., Academic Press, $394 \mathrm{p}$.

Haitjema, H.M., 2006, The role of hand calculations in ground water flow modeling: Ground Water, v. 44, no. 6, p.786-791.

Hill, M.C., 1998, Methods and guidelines for effective model calibration; with application to UCODE, a computer code for universal inverse modeling, and MODFLOWP, a computer code for inverse modeling with MODFLOW: U.S. Geological Survey Water-Resources Investigations Report 98-4005, $90 \mathrm{p}$.

Hunt, R.J., 2006, Ground water modeling applications using the analytic element method: Ground Water, v. 44, no. 1, p. $5-14$.

Hunt, R.J., Anderson, M.P., and Kelson, V.A., 1998, Improving a complex finite-difference ground water flow model through the use of an analytic element screening model: Ground Water, v. 36, no. 6, p. 1011-1017.

Hunt, R.J., Haitjema, H.M., Krohelski, J.T., and Feinstein, D.T., 2003, Simulating ground water-lake interactionsApproaches and insights: Ground Water, v. 41, no. 2 , p. 227-237.

Hunt, R.J., and Krohelski, J.T., 1996, The application of an analytic element model to investigate groundwater-lake interactions at Pretty Lake, Wisconsin: Journal of Lake and Reservoir Management, v. 12, no. 4, p. 487-495.

Juckem, P.F., and Hunt, R.J., 2007, Simulation of the shallow ground-water-flow system near Grindstone Creek and the Community of New Post, Sawyer County, Wisconsin: U.S. Geological Survey Scientific Investigations Report 2007-5014, 29 p. 
Juckem, P.F., Hunt, R.J., and Tyrolt, D.D., 2003, Using characteristic leakage length as a guide to model designApplication to the Grindstone Springs Area, Lac Courte Oreilles, Wisconsin, in American Water Resources Association, Wisconsin state section, proceedings: p. 51.

Poeter, E.P., and Hill, M.C., 1997, Inverse models-A necessary next step in ground-water modeling: Ground Water, v. 35, no. 2, p. 250-260.

Pratt, F.B., 1982, Comprehensive Trout Survey Report, Namekagon River, 1981-1982: unpublished Wisconsin Department of Natural Resources report, 68 p.
Rantz, S.E., and others, 1982, Measurement and computation of streamflow-Volume 1, Measurement of stage and discharge: U.S. Geological Survey Water Supply Paper 2175, 284 p.

Sather, L.M., and Threinen, C.W., 1969, Surface water resources of Sawyer County: Wisconsin Department of Natural Resources, 214 p.

Wolf, P.R., and Ghilani, C.D., 2002, Elementary surveyingAn introduction to geomatics (10th ed.): Englewood Cliffs, N.J., Prentice-Hall, 900 p. 
This page intentionally left blank. 
Publishing support provided by the U.S. Geological Survey

Publishing Network, Columbus and Tacoma Publishing Service Centers

For more information concerning the research in this report, contact the Director, Wisconsin Water Science Center

U.S. Geological Survey

8505 Research Way

Middleton, Wisconsin 53562

http://wi.water.usgs.gov/ 
